\title{
The Life of Walatta-Petros
}





\title{
ThE LIFE OF WALATTA-PETROS
}

A SEVENTEENTH-CENTURY BIOGRAPHY

OF AN AFRICAN WOMAN

CONCISE EDITION

\author{
TRANSLATED AND EDITED BY \\ Wendy Laura Belcher and Michael Kleiner \\ WRITTEN BY GALAWDEWOS
}

PRINCETON UNIVERSITY PRESS

PRINCETON AND OXFORD 
Copyright (c) 2018 by Princeton University Press

Published by Princeton University Press

41 William Street, Princeton, New Jersey 08540

6 Oxford Street, Woodstock, Oxfordshire OX20 1TR

$$
\text { press.princeton.edu }
$$

This book includes material originally published in The Life and Struggles of Our Mother Walatta Petros: A Seventeenth-Century Biography of an Ethiopian Woman (copyright (c) 2015 by Princeton University Press).

Cover art: Walatta Petros counting the hippo's teeth on Lake Tana (SLUB Dresden / Digital Collections / 3.A.6718)

All Rights Reserved

Library of Congress Control Number 2018935646 ISBN 978-0-691-18291-9

British Library Cataloging-in-Publication Data is available

This book has been composed in Linux Libertine 0

Printed on acid-free paper. $\infty$

Printed in the United States of America 